\title{
一塑性理諭の矩形梁への適用
}

\author{
正員工博 星 埜

\section{APPLICATION OF A PLASTIC THEORY TO A RECTANGULAR BEAM}

和*

\author{
Dr. Eng. Kano Hoshino C.E.Member.
}

\begin{abstract}
Synopsis By applying his plastic theory to a rectangular beam, the author has determined the position of the neutral axis in the section, the plastic strain, the distribution of stress and the modulus of rupture at the time of breakage and obtained an approximate deflection curve of a beam.

It is an experimentally well-known fact that, with the increase of the bending moment, the neutral axis is shifted towards the compression side, the distribution of stress changes in the form of a curve and the modulus of rupture becomes greater than the tensile strength. These phenomena as we'l as the eftect of Poisson's ratio on them can be theoretically explained by the author's theory. Besides, it seems that the theory will make it possible to calculate the increase of the bending deflection of beams due to plasticity.
\end{abstract}

1)

要旨 著者の導いた塑性理論を 矩形梁に適用して, 断面に於ける中立軸の位置, 望跣歪ミと応力の分布及び破 少求め且梁の撓填時の曲ら゙强ミ曲線を近似的に導いた。

実験的事実として知られている曲ら゙モーメントが增すと中立軸が圧縮側に偏より応力分布が曲線状に変化する こと, 曲グ强サが引張り强サより大きいとと及びそれらの現象に及ぼすポアッン比の影響なぞを合理的に說明で きるし, 又塑性による梁の撓ミ沈下の增大を推算し得るようである。

\section{1. ま がき}

さきに著者は土のような塑性材料の変形之破壊についての 1 法則の誘導を試み, それが単純淔応力, 純粋剪断, 圧密，静水圧等を5ける場合の変形と破壞についての実験的事害をかなり合理的に説明できるととを示した。

著者の塑性理袷は土に限らず引張り又は圧縮を5けを時，応力の增加につれて歪ミの聥增を見せて終いに破 壊し，しかもその引張り強サが圧縮強サにくらべて一般に小さい上5な性質を示す材料に広く適用することがて

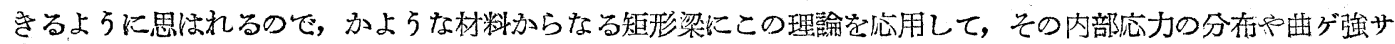
学求め, 叉梁の䔲ミ沈下を近似的に算定する公式学求めて見を。

考察に当つては次のよ 5 に仮定した。

a. 梁の各断面は変形の後も平面を保つものとする。 b. 剪断力の影響怔無視する。

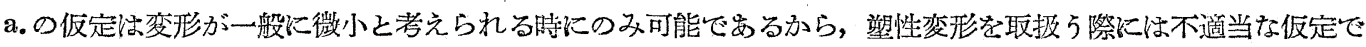
女ると考えられるが，塑性の影響は曲ゲモーメントが大きい部分に主として現はれ然も普通の梁では曲ゲモーメ ントの大きい部分で、の仮定が略成立つものと考えてよい。特に対称荷重を5ける梁の中央断面に於ては、の仮 定がその末ま当はするのでその曲ゲ強サを正しく求めることができる。b の仮定は梁の高さに比しスパンが特に 短かく梁の支点附近で破壊が起るよ5な場合を除いて応力の算定には㐙つふえないが，変形の計算には一般に不 適当であつて，梁の撓ミ沈下曲線つ形にかなりの影響を及滦するのと考えられる。然しこっで計計算を容易なら しめるため，この仮定を执いて近似的に取扱らにとら゙めた。

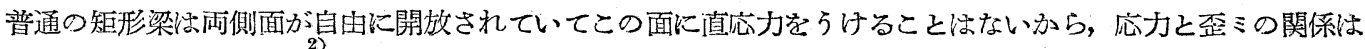
3 次元直応力 (B2)の場合裳用いることができる。若し梁の幅が充分広く, 変形際して側方えの幅の伸縮か浣 全に妨げられていると仮定できる時は，2次元平面変形 (A2) の場合を用いれ注よい。A2 とB2 との場合に， 忘力と至ミとの関係が恨同じ形の式で表わされるので，2つの場合学同時に考えることにした。

* 東大敎授 第二工学部

1）土のよ5な塑性材料の変形と破壞についての基礎理諭 土木学会論文集 昭和 22,23 年度, 昭和 24 年 3 月

2) 前出論文集 95頁參照

3) 前出論文集 93 頁参照 


\section{2. 梁の断面に於ける歪ミと応力}

梁の断面飞於て，その高学 $h$, 中立軸から $y$ ぞけ離れた点の歪ミ度 $\varepsilon$ 结 $y$ に比 例するものとし且つ $y=h / 2$ に於ける歪ミ度を $e$ とすれば（図一 1 参照）

$$
\bar{\varepsilon}=\frac{2 e}{h} y \text {. }
$$

応力 $\bar{\sigma}$ と歪ミ $\bar{\varepsilon}$ の関係峈次式で表わされる。

$$
\begin{aligned}
& \bar{\varepsilon} \times \frac{r_{0}}{\sigma_{0}}=\gamma\left\{\sin ^{-1} \alpha-\sin ^{-1}\left(\alpha-\beta \frac{\bar{\sigma}}{\sigma_{0}}\right)\right\} \\
& \text { こに A2 (plane strain): } \quad \alpha=\frac{3 \sqrt{2} \mu}{\sqrt{9+12 \mu^{2}+16 \mu^{4}}} \\
& \beta=\frac{9-6 \mu^{2}+16 \mu^{4}}{2 \sqrt{2} \mu\left(3+2 \mu^{2}\right) \sqrt{9+12 \mu^{2}+16 \mu^{4}}} \\
& \gamma=\frac{3+8 \mu^{2}}{2 \sqrt{2} \mu \sqrt{9-16 \mu^{2}+16 \mu^{4}}}
\end{aligned}
$$

B2(Space stress):

$$
\begin{aligned}
& \alpha=\sqrt{\frac{2}{3} \mu} \\
& \beta=\sqrt{\frac{2}{3} \frac{3-2 \mu^{2}}{6 \mu}} \\
& \gamma=\frac{3+2 \mu^{2}}{\mu \sqrt{2\left(3-2 \mu^{2}\right)}}
\end{aligned}
$$

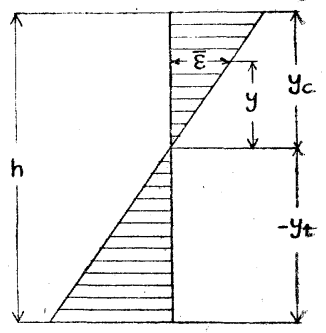

図一2 㤝力一歪ミ曲線の例で安る。本式快次 の如く畫き改めることができる。

$$
\frac{\bar{\sigma}}{\sigma_{0}}=\frac{1}{\beta}\left\{\alpha-\sin \left(\sin ^{-1} \alpha-\frac{V_{0}}{\gamma \sigma_{0}} \bar{\varepsilon}\right)\right\} \cdots(3)
$$

式 (1) k於て

$$
\varphi=\frac{V_{0}}{\gamma \sigma_{0}} e
$$

と特けば

$$
\bar{\varepsilon} \frac{V_{0}}{\gamma \sigma_{0}}=2 p \frac{y}{h}
$$

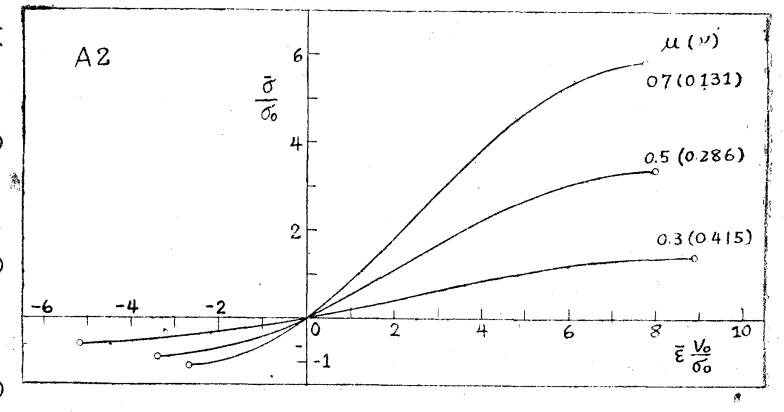

を得るから, 式 ( 3 ) に代入乙て

$$
\frac{\bar{\sigma}}{\sigma_{0}}=\frac{1}{\beta}\left\{\alpha-\sin \left(\sin ^{-1} \alpha-2 \rho \frac{y}{h}\right)\right\}
$$

本式に上つて梁の断面に於ける応力分布が与号ら れる。

次に梁の中立軸の位置を決定するため，梁の幅 を $b$ として，圧縮側と引張側の応力の総和をそれ ぞれ $C$ 及び $T$ とすると

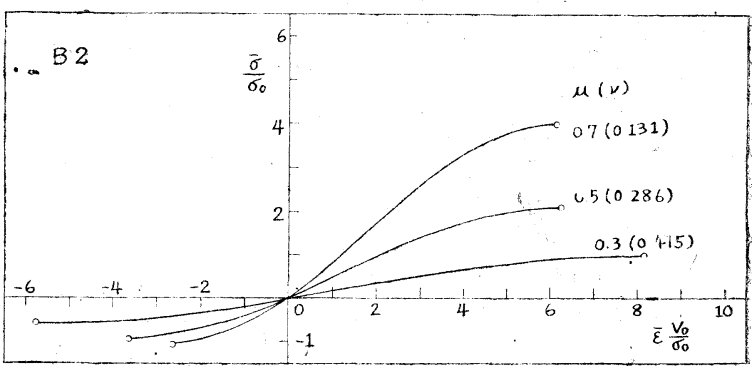

$$
\begin{aligned}
& C=\int_{0}^{y_{c}} b \overline{\sigma \sigma} d y=\frac{\sigma_{0}}{\beta} \int_{0}^{y_{c}} b\left\{\alpha-\sin \left(\sin ^{-1} \alpha-2 \Phi \frac{y}{h}\right)\right\} d y \\
& T=\int_{0}^{-y_{t}} b \bar{\sigma} d y=\frac{\sigma_{0}}{\beta} \int_{0}^{-y} t b\left\{\alpha-\sin \left(\sin ^{-1} \alpha-2 \Phi \frac{y}{h}\right)\right\} d y
\end{aligned}
$$

式中 $y_{c}, y_{t}$ : 梁の中立軸から上端及び下端をでの高サ（図一1)。

矩形梁の場合は $b$ 一定として積分すると

$$
\begin{aligned}
& C=\frac{b h \sigma_{0}}{\beta}\left\{\alpha \frac{y_{c}}{h}-\frac{1}{2 \Phi} \cos \left(\sin ^{-1} \alpha-2 \Phi \frac{y_{c}}{h}\right)+\frac{1}{2 \Phi} \cos \left(\sin ^{-1} \alpha\right)\right\} \\
& T=\frac{b h \sigma_{0}}{\beta}\left\{-\alpha \frac{y_{t}}{h}-\frac{1}{2 \Phi} \cos \left(\sin ^{-1} \boldsymbol{\alpha}+2 \phi \frac{y_{t}}{h}\right)+\frac{1}{2 \Phi} \cos \left(\sin ^{-1} \alpha\right)\right\}
\end{aligned}
$$


$C=T$ と特き且 $y_{c}=h-y_{t}$ であるから

$$
\begin{aligned}
& \cos \left(\sin ^{-1} \alpha-2 \phi \frac{h-y_{t}}{h}\right)-\cos \left(\sin ^{-1} \alpha+2 \phi \frac{y_{t}}{h}\right)=2 \alpha \phi \\
& -2 \sin \left(\sin ^{-1} \alpha+\phi \frac{2 y_{t}-h}{h}\right) \sin \left(\phi \frac{-h}{h}\right)=2 \alpha \phi
\end{aligned}
$$

เつて

$$
\frac{y_{t}}{h}=\rho=\frac{1}{2}\left[1+\frac{1}{\phi}\left\{\sin ^{-1}\left(\frac{\alpha \rho}{\sin \phi}\right)-\sin ^{-1} \alpha\right\}\right]
$$

従つて梁の上下端に於ける歪ミ度と縁応力は式 (5) 反び式 (6) に於てそれぞれ $y=-y_{t}, y=h-y_{t}$ と特いて

引㲀側

$$
\begin{array}{cc}
\text { 引張側 } & \bar{\varepsilon} \frac{V_{0}}{\sigma_{0}}=-\gamma\left\{\rho+\sin ^{-1}\left(\frac{\alpha \phi}{\sin \phi}\right)-\sin ^{-1} \alpha\right\} \\
& \frac{\bar{\sigma}}{\sigma_{0}}=-\frac{1}{\beta}\left[-\alpha+\sin \left\{\phi+\sin ^{-1}\left(\frac{\alpha \phi}{\sin \phi}\right)\right\}\right] \\
\text { 压縮側 } & \bar{\varepsilon} \frac{V_{0}}{\sigma_{0}}=\gamma\left\{\rho-\sin ^{-1}\left(\frac{\alpha \Phi}{\sin \phi}\right)+\sin ^{-1} \alpha\right\} \\
& \frac{\bar{\sigma}}{\sigma_{0}}=\frac{1}{\beta}\left[\alpha+\sin \left\{\phi-\sin ^{-1}\left(\frac{\alpha \phi}{\sin \phi}\right)\right\}\right]
\end{array}
$$

\section{3. 応カによる曲ゲモーメント}

次に断面に生ずる応力による曲ゲモーメントを求めると

$$
\begin{aligned}
& M=b \int_{-y_{t}}^{y_{c}} \bar{\sigma} \bar{y} d y \\
& =\frac{b \sigma_{0}}{\beta} \int_{-y t}^{h-y t}\left\{\alpha-\sin \left(\sin ^{-1} \alpha-2 \phi \frac{y}{h}\right)\right\} y d y \\
& =\frac{b \sigma_{0}}{\beta}\left[\frac{\alpha}{2} y^{2}-\frac{h}{2 \Phi} y \cos \left(\sin ^{-1} \alpha-2 \phi \frac{y}{h}\right)-\frac{h^{2}}{4 \Phi^{2}} \sin \left(\sin ^{-1} \alpha-2 \phi \frac{y}{h}\right)\right]_{-y t}^{h-y t} \\
& =\frac{b h^{2} \sigma_{0}}{2 \beta}\left[\alpha\left(1-2 \frac{y_{t}}{h}\right)-\frac{1}{\Phi}\left(1-\frac{y_{t}}{h}\right) \cos \left\{\sin ^{-1} \alpha-2 \Phi\left(1-\frac{y_{t}}{h}\right)\right\}-\frac{1}{\phi} \frac{y_{t}}{h} \cos \left(\sin ^{-1} \alpha+2 \phi \frac{y_{t}}{h}\right)\right. \\
& \left.-\frac{1}{2 \Phi^{2}} \sin \left\{\sin ^{-1} \alpha-2 \Phi\left(1-\frac{y_{t}}{h}\right)\right\}+\frac{1}{2 \Phi^{2}} \sin \left(\sin ^{-1} \alpha+2 \phi \frac{y_{t}}{h}\right)\right]
\end{aligned}
$$

式 (8)の $y_{t} / h$ を代大して整理すれば

$$
\begin{gathered}
M=W \sigma_{0} \frac{3}{\beta}\left(\frac{1}{\Phi}-\cot \phi\right) \sqrt{\left(\frac{\sin \varphi}{\phi}\right)^{2}-\alpha^{2}} . \\
\text { 但し } W=\frac{b h^{2}}{\sigma} \quad \text { 断面係数 }
\end{gathered}
$$

梁の外力による各断面の曲ゲモーメントが与えられる時, 本式から逆にのの值を求め, 式 (8) よら中立軸の 位置を, 式 (5) 及び (6) 上りそれぞれ歪ミと応力の分布を, 叉式 (9) 上り断面の上下端に䍅ける歪ミ度と 縁応力を決定することができる。

\section{4. 梁の破壊條件と曲ゲ强サ}

梁の破壊は引張側の最大赭力が引張強サの限界に達した時に起るものとすることがゼきる。然るに材料の引 張り強サは理論上 $\overline{d \sigma} / d \bar{\varepsilon}=0$ なる条件から求められるから, 式 (3) にこの条件を適用して

$$
\bar{\varepsilon} \cdot \frac{V_{0}}{\sigma_{0}}=-\gamma\left(\frac{\pi}{2}-\sin ^{-1} \alpha\right)
$$

を得, 従つてこの值を式 (3) に代大して引張強サを求めると

$$
\frac{\bar{\sigma}}{\sigma_{0}}=-\frac{1}{\beta}(1-\alpha) \text {. }
$$

式 (9) の引張側比ける応力が式 (11) の值敒等しいと抬いて

$$
\sin \left\{\phi+\sin ^{-1}\left(\frac{\alpha \phi}{\sin \phi}\right)\right\}=1
$$

なる関倸を得るから，これょり矩形梁の破壊条件として

$$
\frac{\sin 2 \phi}{2 \phi}=\alpha
$$

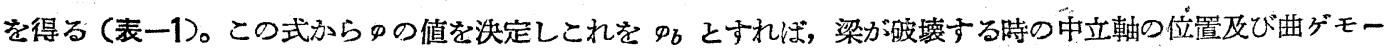


メントは

$$
\left.\begin{array}{l}
\frac{y_{t b}}{h}=\rho_{b}=\frac{1}{2 \Phi_{b}}\left\{\frac{\pi}{2}-\sin ^{-1} \alpha\right\} \\
M_{b}=W \sigma_{0} \frac{3}{\beta}\left(\frac{1}{\Phi_{b}}-\cot \Phi_{b}\right) \sqrt{\left(\frac{\sin \varphi_{b}}{\Phi_{b}}\right)^{2}-\alpha^{2}}
\end{array}\right\}
$$

従つて梁の曲ゲ強サを $m_{b} \sigma_{0}$ とすると

$$
m_{b}=\frac{M_{b}}{W \sigma_{0}}=\frac{3}{\beta}\left(\frac{1}{\Phi_{b}}-\cot \Phi_{b}\right) \sqrt{\left(\frac{\sin \Phi_{b}}{\Phi_{b}}\right)^{2}-\alpha^{2}}
$$

娥壊を生ずる断面の上下端に於ける歪ミ度と縁応力はそれぞれ次の如くなる。

引張側 $\bar{\varepsilon} \frac{V_{0}}{\sigma_{0}}=-\gamma\left\{\frac{\pi}{2}-\sin ^{-1} \alpha\right\}$

$$
\frac{\bar{\sigma}}{\sigma_{0}}=-\frac{1}{\beta}(1-\alpha)
$$

\begin{tabular}{c|c}
\multicolumn{2}{c}{ 表一1 } \\
\hline$\phi$ & \multicolumn{1}{|c}{$\alpha$} \\
\hline 0.6 & 0.7767 \\
0.7 & 0.7039 \\
0.8 & 0.6247 \\
0.9 & 0.5410 \\
1.0 & 0.4546 \\
1.1 & 0.3675 \\
1.2 & 0.2814 \\
1.3 & 0.1983 \\
1.4 & 0.1196 \\
1.5 & 0.0470 \\
$\pi / 2$ & 0 \\
\hline
\end{tabular}

圧縮側

$$
\begin{aligned}
& \bar{\varepsilon} \frac{V_{0}}{\sigma_{0}}=\gamma\left(2 \varphi_{b}-\frac{\pi}{2}+\sin ^{-1} \alpha\right) \\
& \bar{\sigma} \sigma_{0}=\frac{1}{\beta}\left(\alpha-\cos 2 \Phi_{b}\right)
\end{aligned}
$$

5. 結果に対する考察

材料の力学的常数 $\mu$ に対する $\Phi_{b}, m_{b}$ 及び $\rho_{b}$ の值を求めると, 図-3, 図-4 及び図-5(表一2, 表一3) が得 られる。

$$
\mu=\sqrt{\frac{3(1-2 \nu)}{4(1+\nu)}}
$$

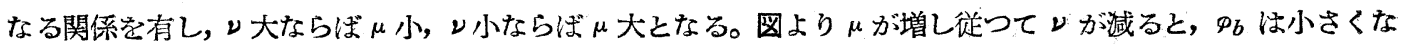

図-3

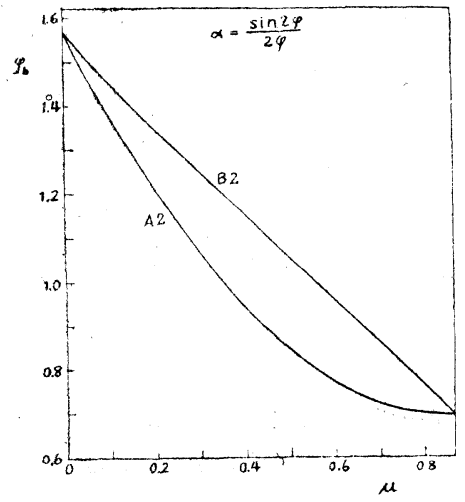

表-2 A2

\begin{tabular}{l|rcrccc}
\hline \multicolumn{1}{c|}{} & $\boldsymbol{\alpha}$ & $\boldsymbol{c}$ & \multicolumn{1}{c}{$\gamma$} & $\phi_{b}$ & $m_{b}$ & $\rho_{b}$ \\
\hline 0 & 0 & $\infty$ & $\infty$ & 1.5708 & 0 & 0.5000 \\
0.1 & 0.140 & 3.460 & 11.92 & 1.3725 & 0.3202 & 0.5205 \\
0.2 & 0.275 & 1.636 & 5.95 & 1.2073 & 0.5948 & 0.5350 \\
0.3 & 0.399 & 0.999 & 4.49 & 1.0629 & 0.8305 & 0.5454 \\
$\mathbf{0 . 4}$ & 0.505 & 0.668 & 3.90 & 0.9423 & 1.0425 & 0.5528 \\
$\mathbf{0 . 5}$ & 0.588 & 0.476 & 3.63 & 0.8437 & 1.2326 & 0.5578 \\
$\mathbf{0 . 6}$ & 0.649 & 0.360 & 3.48 & 0.7696 & 1.4017 & 0.5613 \\
$\mathbf{0 . 7}$ & 0.688 & 0.290 & 3.33 & 0.7218 & 1.5579 & 0.5634 \\
$\mathbf{0 . 8}$ & 0.705 & 0.251 & 3.14 & 0.6980 & 1.7064 & 0.5642 \\
$\mathbf{0 . 8 6 6}$ & 0.707 & 0.235 & 3.00 & 0.6956 & 1.8041 & 0.5643 \\
\hline
\end{tabular}

図-4
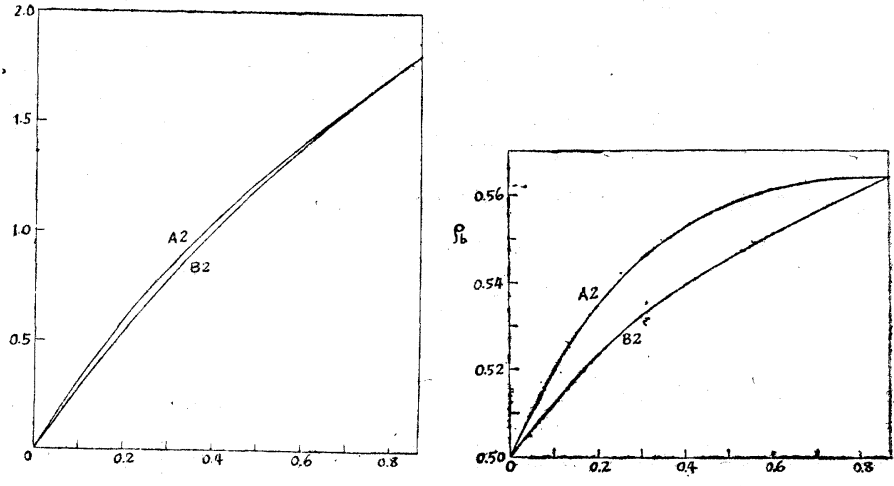

表一3 B2

\begin{tabular}{l|cccccc}
\hline$\mu$ & $\alpha$ & $\beta$ & $\gamma$ & $\Phi_{b}$ & $m_{b}$ & $\rho_{b}$ \\
\hline 0 & 0 & $\infty$ & $\infty$ & 1.5708 & 0 & 0.5000 \\
0.1 & 0.0816 & 4.050 & 12.38 & 1.4513 & 0.2861 & 0.5128 \\
0.2 & 0.1632 & 1.987 & 6.37 & 1.3443 & 0.5476 & 0.5236 \\
0.3 & 0.2448 & 1.278 & 4.46 & 1.2431 & 0.7861 & 0.5322 \\
0.4 & 0.3264 & 0.912 & 3.59 & 1.1481 & 1.0033 & 0.5396 \\
0.5 & 0.4080 & 0.680 & 3.13 & 1.0540 & 1.2018 & 0.5463 \\
0.6 & 0.4896 & 0.517 & 2.90 & 0.9604 & 1.3857 & 0.5517 \\
0.7 & 0.5712 & 0.392 & 2.83 & 0.8640 & 1.5579 & 0.5567 \\
0.8 & 0.6528 & 0.292 & 2.89 & 0.7664 & 1.7103 & 0.5616 \\
0.866 & 0.7071 & 0.235 & 3.00 & 0.6956 & 1.8041 & 0.5643 \\
\hline
\end{tabular}


ク， $m_{b}$ と $\rho_{b}$ とは大きくなることを知る。これは $\sigma_{0}$ の等しい場合に梁の曲ら゙強サは $\mu$ が大きい程大きく，又破 壊時に於ける中立軸の偏りも $\mu$ が大きい程大きいことを示している。 $\rho_{b}$ の最大は $\mu=0.866$ に於て 0.5643 とな つていて，中立軸が梁高の $6.43 \%$ チ゚け偏倚することを示す。A2 (plane strain) とB2 (Space stress) の場合 を比較すると， $m_{b}$ \& $\rho_{b}$ もA2 の方が大きいが， $\mu$ が 0 㕛は 0.866 に近い程との差は少なくなり，特比 $m_{b}$ の差は一般に僅が市る。

今材料の曲ゲ強サ，引張り強サ及び圧縮強サを比較するため，それぞれの強サを $\sigma_{0}$ で割つた值を $m, t$ 及 びcとすると，それらの比悰図一6のよ5になる(表一4, 表一5)。この 図から圧縮強サに対する曲ゲ強サと引張り強サの比は何れも $\mu$ が大きい と小さくなり然もA2 のうがB2 より小さくなつているが，曲が強サの 引張り強サに対寸る比は $\mu$ が大きい活ど大きくその範囲は 1.212 より 1.451 の間にあり，A2 の方がB2 よりや人大さなつている。

ポアソン比レが 0.13 であるよ5な材料学例にとると， $\mu$ は 0.70 と なるから，B2 の場合に図一6(表一4) から

$$
m / t=1.423, m / c=0.389, t / c=0.272
$$

実測の結果によると $m / t$ は鋳鉄で 1.7, コンクリートで $1.5 \sim 2.0$ と なつて括り, 計算值はや小小さすぎる。叉コンクリートの $t / c は 0.1$ 程 度， $m / c$ は $1 / 7 \sim 1 / 5$ と云われるから詮算値は何れも過大である。曲ら゙強 サを一応の基準にとつて見ると, 実測值は計算値に対し $t$ が 0.8 倍, $c$ が2.0 倍程度となつている。この相違は必ずしも理論の不備に起因する ものと云らわけでなく, 試験片の内部応力が破壊の際に不均一な分布を 示し, 破壊が一局部から起つて段々㹡大寸ると云らような現象が大きく 影響していると考えられるし，又試験片の支持状態の影響も考えられ る。量的な一致を得るにはこのよ5な点を考慮して理諭を組立てなけれ ばならないが，著者の塑性理論から導かれた結論は材料の実験的な力学

図-6

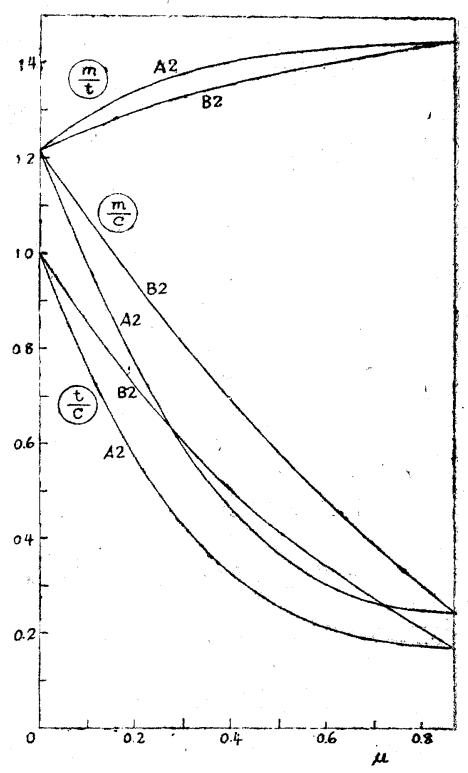
的諸性質之傾向的に矛盲することなくその変形と破壞の機構を巧みに説明することができるよらに思われる。

表一4 A2

\begin{tabular}{l|lllllc}
\hline$\mu$ & $m$ & $t$ & $c$ & $m / t$ & $m / c$ & $t / c$ \\
\hline 0 & 0 & 0 & 0 & 1.212 & 1.212 & 1.000 \\
0.1 & 0.320 & 0.248 & 0.329 & 1.291 & 0.973 & 0.753 \\
0.2 & 0.595 & 0.443 & 0.779 & 1.343 & 0.763 & 0.569 \\
0.3 & 0.830 & 0.603 & 1.401 & 1.377 & 0.593 & 0.430 \\
0.4 & 1.043 & 0.743 & 2.260 & 1.405 & 0.461 & 0.328 \\
0.5 & 1.233 & 0.865 & 3.342 & 1.425 & 0.369 & 0.259 \\
0.6 & 1.402 & 0.976 & 4.600 & 1.436 & 0.305 & 0.212 \\
0.7 & 1.558 & 1.080 & 5.821 & 1.443 & 0.267 & 0.185 \\
0.8 & 1.706 & 1.180 & 6.793 & 1.447 & 0.251 & 0.173 \\
0.866 & 1.804 & 1.243 & 7.242 & 1.451 & 0.249 & 0.172 \\
\hline
\end{tabular}

表一5 B2

\begin{tabular}{l|llllll}
\hline$\mu$ & $m$ & $t$ & $c$ & $m / t$ & $m / c$ & $t / c$ \\
\hline 0 & 0 & 0 & 0 & 1.212 & 1.212 & 1.000 \\
0.1 & 0.286 & 0.227 & 0.267 & 1.260 & 1.071 & 0.850 \\
0.2 & 0.548 & 0.421 & 0.586 & 1.301 & 0.930 & 0.719 \\
0.3 & 0.786 & 0.590 & 0.973 & 1.332 & 0.808 & 0.606 \\
0.4 & 1.003 & 0.739 & 1.455 & 1.358 & 0.690 & 0.507 \\
0.5 & 1.202 & 0.870 & 2.071 & 1.381 & 0.580 & 0.420 \\
0.6 & 1.386 & 0.987 & 2.881 & 1.404 & 0.481 & 0.342 \\
0.7 & 1.558 & 1.091 & 4.002 & 1.423 & 0.389 & 0.272 \\
0.8 & 1.710 & 1.185 & 5.651 & 1.443 & 0.303 & 0.210 \\
0.866 & 1.804 & 1.243 & 7.242 & 1.451 & 0.249 & 0.172 \\
\hline
\end{tabular}

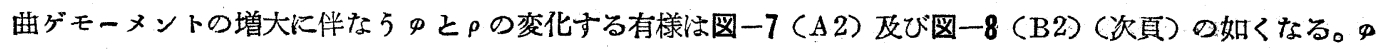

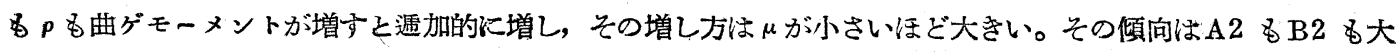
きな差異はない。

曲ゲモーメントが增すとき，断面の歪み度と応力の分布が変化する様子はA2 で $\mu$ が $0.3,0.5$ 及び 0.7 の場 合について図示すると図一9 (次頁) のよ5になる。

\section{6. 矩形梁の撓ミ曲線}

淘性材䊀からなる梁の撓ミは破壊に近付くとかなり大きくなるが，塑性の影響は梁の中央附近に著しく表われ るから，取扱い上の便宜を考えて次式が近似的に成立つるのと仮定することがでよう。

$$
\frac{d^{2} \eta}{d x^{2}}=-\frac{2 e}{h}=-\frac{2 \gamma \sigma_{0}}{V_{0} h}
$$


図-7
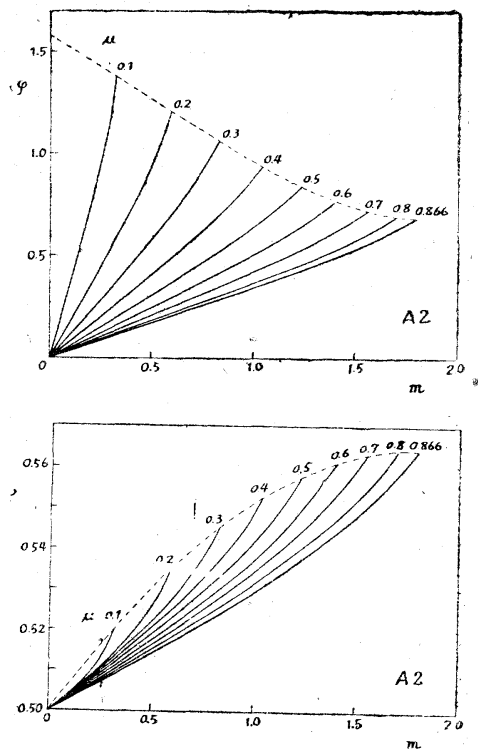

然るに式 (10) から

$$
m=\frac{M}{W \sigma_{0}}=\frac{3}{\beta}\left(\frac{1}{\phi}-\cot \phi\right) \sqrt{\left(\frac{\sin \phi}{\Phi}\right)^{2}-\alpha^{2}}
$$

展開して次式を得る。

$$
\begin{aligned}
& m=\frac{1}{k}\left\{\phi-i_{3} \Phi^{3}-i_{5} \Phi^{5}-i_{7} \Phi^{7}-\cdots \cdots\right\} \cdots \cdots \cdots \cdot(17) \\
& \text { こた } \quad k=\frac{\beta}{\sqrt{1-\alpha^{2}}} \\
& i_{3}=\frac{1}{6\left(1-\alpha^{2}\right)}-\frac{1}{15} \\
& i_{5}= \frac{1}{9}\left\{\frac{1}{8\left(1-\alpha^{2}\right)^{2}}-\frac{1}{10\left(1-\alpha^{2}\right)}-\frac{2}{35}\right\} \\
& i_{7}= \frac{1}{9}\left\{\frac{1}{48\left(1-\alpha^{2}\right)^{3}}-\frac{1}{40\left(1-\alpha^{2}\right)^{2}}\right. \\
&\left.+\frac{11}{1050\left(1-\alpha^{2}\right)}-\frac{1}{175}\right\}
\end{aligned}
$$

本式を逆比展開し直年と次式を得る。

$$
\begin{gathered}
\varphi=k m+j_{3}(k m)^{3}+j_{5}(k m)^{5}+j_{7}(k m)^{7}+ \\
\text { こ小に } j_{3}=i_{3} \\
j_{5}=3 i_{3}{ }^{2}+i_{5} \\
j_{7}=13 i_{3}{ }^{3}+8 i_{3} i_{5}+i_{7}
\end{gathered}
$$

梁の任意の断面に於ける曲ゲモーメントを $\boldsymbol{M}=m \sigma_{0} W$, 最大の曲ゲモーメントを $M_{0}=m_{0} \sigma_{0} W$ として

$$
\lambda=\frac{M}{M_{0}}=\frac{m}{m_{0}}
$$

と特き且梁の支間をしとして

$$
\xi=\frac{2 x}{l}
$$

上特くと，入 は梁の各点に於ける曲ゲモーメントの分布を 示し $x$ 従つて $\xi$ の函数で表わされる。且 $\frac{d^{2} \eta}{d x^{2}}=\frac{4}{l^{2}} \frac{d^{2} \eta}{d \xi^{2}}$ であるから式 (16) と式 (18) から

$$
\frac{d^{2} \eta}{d \xi^{2}}=-\frac{\gamma \sigma_{0} l^{2}}{2 V_{0} h}\left\{k \lambda m_{0}+j_{3}\left(k \lambda m_{0}\right)^{3}+j_{5}\left(k \lambda m_{0}\right)^{5}+j_{7}\left(k \lambda m_{0}\right)^{7}+\cdots \cdots \cdot\right\}
$$

図-8
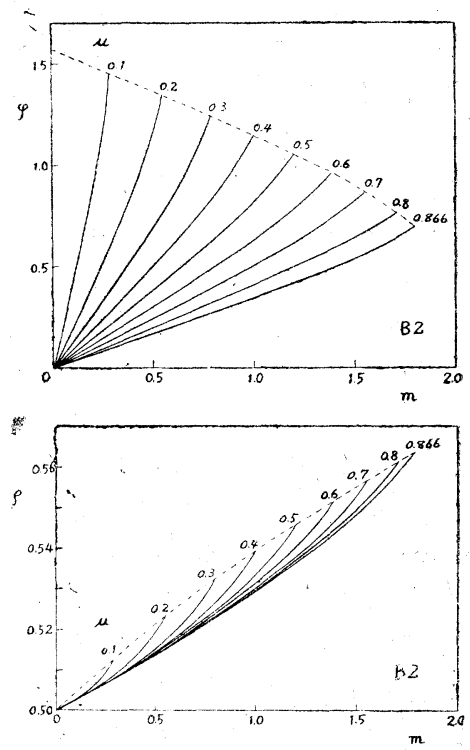

図-9
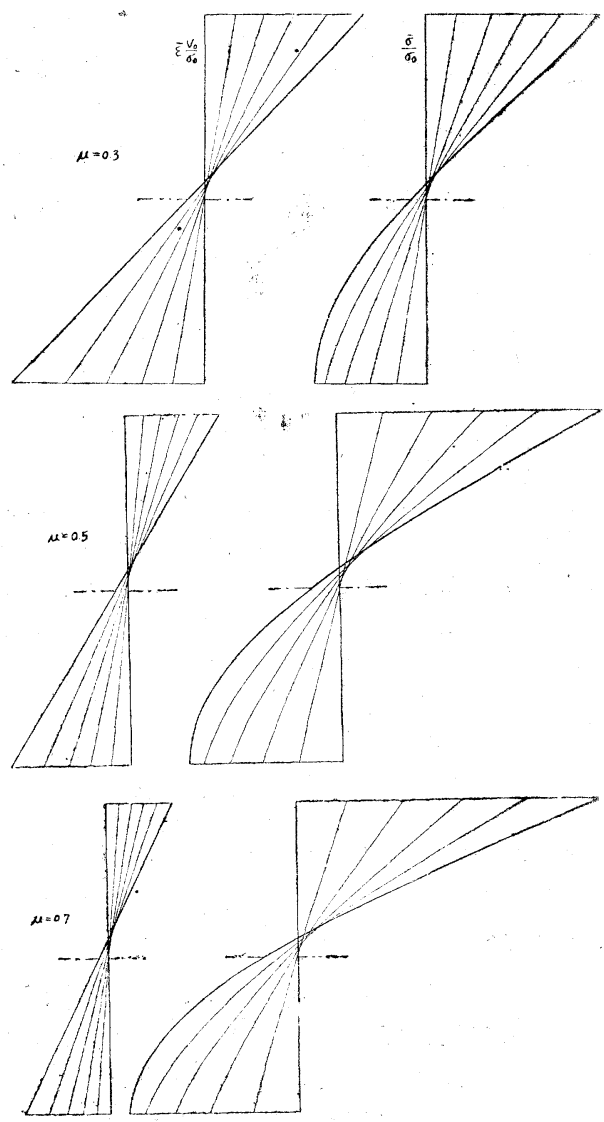
積分して撓ミ曲線を求めると

$$
\eta=c^{\prime \prime}+c^{\prime} \xi-\frac{\gamma \sigma_{0} l^{2}}{2 V_{0} h}\left\{k m_{0} \iint \lambda d \xi d \xi+j_{3} k^{3} m_{0}^{3} \iint \lambda^{3} d \xi d \xi+j_{5} k^{5} m_{0}{ }^{5} \iint \lambda^{5} d \xi d \xi+j_{7} k^{7} m_{0}{ }^{7} \iint \lambda^{7} d \xi d \xi+\cdots \cdots . . \cdots \cdots(21)\right.
$$

曲ゲモーメントの分布郎ら入が与えられる時は，本式の積分を行い，境界条件から $c^{\prime}$ 及び $e^{\prime \prime}$ を浃定して梁の撓 ミ曲線を定めることができる。

単梁の場合について (1) 中央に集中荷重岀る時と (2) 満載等分布荷重の時の撓ミ曲線を

$$
\eta=\frac{\gamma \sigma_{0} l^{2}}{2 V_{0} h}\left\{k m_{0} \psi_{1}+j_{3} k^{3} m_{0}{ }^{3} \psi_{3}+j_{5} k^{5} m_{0}{ }^{5} \psi_{5}+j 7 k^{7} m_{0}{ }^{7} \psi_{7}+\cdots \cdots \cdot\right\}
$$

と招いて $\psi_{1}, \psi_{3}, \psi_{5}, \psi_{7}$ 等学求めて見上弓。

(1) 中央に集中荷重 $P$ がある時の単梁の 撓ミ

$$
M=\frac{P x}{2}, \quad M_{0}=\frac{P l}{4}, \therefore m_{0}=\frac{P l}{4 W \sigma_{0}}
$$

であるから

$$
\lambda=\frac{M}{M_{0}}=\frac{2 x}{l}=\xi
$$

積分して境界条件を入れると

$$
\begin{aligned}
& \psi_{1}=\frac{1}{2}\left(\xi-\frac{\xi^{3}}{3}\right) \\
& \psi_{3}=\frac{1}{4}\left(\xi-\frac{\xi^{5}}{5}\right) \\
& \psi_{5}=\frac{1}{6}\left(\xi-\frac{\xi^{7}}{7}\right) \\
& \psi_{7}=\frac{1}{8}\left(\xi-\frac{\xi^{9}}{9}\right)
\end{aligned}
$$

梁の中央に於ける撓ミを求めるには $\xi=1$ と 括いて

$$
\psi_{1}=\frac{1}{3}, \quad \psi_{3}=\frac{1}{5}, \quad \psi_{5}=\frac{1}{7}, \quad \psi_{7}=\frac{1}{9}
$$

荷重 $P$ が小さい間は $M_{0}$ 従つて $m_{0}$ が小 さいから式 (22) の第 1 項げけを取ると

$$
\begin{aligned}
\eta & =\frac{\gamma \sigma_{0} l^{2}}{2 V_{0} h} k m_{0} \psi_{1} \\
& =\frac{\gamma \sigma_{0} l^{2}}{2 V_{0} h} \frac{\beta}{\sqrt{1-\alpha^{2}}} \frac{P l}{4 W \sigma_{0}} \frac{1}{2}\left(\xi-\frac{\xi^{3}}{3}\right)
\end{aligned}
$$

然るに断面 2 次モーメント $J$ は $W h / 2$ に等
表一6 A2

\begin{tabular}{l|ccccccc}
\hline$\mu$ & $k$ & $i_{3}$ & $i_{5}$ & $i_{7}$ & $j_{3}$ & $j_{5}$ & $j_{7}$ \\
\hline 0 & $\infty$ & 0.1000 & -0.0036 & 0 & 0.1000 & 0.0264 & 0.0091 \\
0.1 & 3.495 & 0.1033 & -0.0032 & 0.0001 & 0.1033 & 0.0289 & 0.0107 \\
0.2 & 1.701 & 0.1134 & -0.0016 & 0.0003 & 0.1134 & 0.0371 & 0.0169 \\
0.3 & 1.087 & 0.1315 & 0.0001 & 0.0007 & 0.1315 & 0.0520 & 0.0284 \\
0.4 & 0.775 & 0.1567 & 0.0037 & 0.0015 & 0.1567 & 0.0775 & 0.0517 \\
0.5 & 0.589 & 0.1880 & 0.0091 & 0.0029 & 0.1880 & 0.1150 & 0.0958 \\
0.6 & 0.474 & 0.2213 & 0.0159 & 0.0039 & 0.2213 & 0.1629 & 0.1617 \\
0.7 & 0.400 & 0.2497 & 0.0226 & 0.0074 & 0.2497 & 0.2098 & 0.2397 \\
0.8 & 0.354 & 0.2646 & 0.0265 & 0.0089 & 0.2646 & 0.2365 & 0.2870 \\
0.866 & 0.333 & 0.2666 & 0.0270 & 0.0091 & 0.2666 & 0.2403 & 0.2965
\end{tabular}

表-7 B2

\begin{tabular}{l|ccccccc}
\hline$\mu$ & $k$ & $i_{3}$ & $i_{5}$ & $i_{7}$ & $j_{3}$ & $j_{5}$ & $j_{7}$ \\
\hline 0 & $\infty$ & 0.1000 & -0.0036 & 0 & 0.1000 & 0.0264 & 0.0091 \\
0.1 & 4.066 & 0.1011 & -0.0035 & 0.0001 & 0.1011 & 0.2710 & 0.0095 \\
0.2 & 2.014 & 0.1045 & -0.0031 & 0.0001 & 0.1045 & 0.0296 & 0.0107 \\
0.3 & 1.318 & 0.1106 & -0.0025 & 0.0002 & 0.1106 & 0.0341 & 0.0148 \\
0.4 & 0.965 & 0.1198 & -0.0014 & 0.0004 & 0.1198 & 0.0418 & 0.0194 \\
0.5 & 0.745 & 0.1333 & 0.0003 & 0.0008 & 0.1333 & 0.0537 & 0.0299 \\
0.6 & 0.593 & 0.1525 & 0.0031 & 0.0014 & 0.1525 & 0.0730 & 0.0472 \\
0.7 & 0.478 & 0.1807 & 0.0078 & 0.0025 & 0.1807 & 0.1059 & 0.0846 \\
0.8 & 0.386 & 0.2237 & 0.0165 & 0.0052 & 0.2237 & 0.1665 & 0.1691 \\
0.866 & 0.333 & 0.2666 & 0.0270 & 0.0091 & 0.2666 & 0.2403 & 0.2965 \\
\hline
\end{tabular}

しく, $\frac{\sqrt{1-\alpha^{2}}}{\beta \gamma} V_{0}$ は応力一歪ミ曲線つ初期接線係数で B 2 の場合は $E$ に等しい名ら上式は

$$
\eta=\frac{1}{48} \frac{P l^{3}}{E J} \times \frac{3}{2} \xi\left(1-\frac{\xi^{2}}{3}\right)
$$

上なつて弾性理䄖の結果と一致する。

梁が破壊する時の撓ミ曲線俚式 (14) 加求をる $m_{b}$ の值を $m_{0}$ に代大して計算すれば求をる，図一10 (次頁) は破壊の際の撓ミ曲線を求め, 弾性計算の場合と比較したものである。又図一11(次頁) は曲ゲモーメントの增 大に伴い梁の中点に於ける撓ミが増大する模様を計算したものでやはり弾性沈下との比較を示した。塑性による 撓ミの増大量は思つたほど大きくないようである。

(2) 满載等布荷重 $p$ に上る単梁の撓ミ

$$
M=\frac{p}{2} x(l-x), \quad M_{0}=\frac{p l^{2}}{8}
$$

ゼあるから

$$
\lambda^{\prime}=M / M_{0}=\xi(2-\xi)
$$

6). 式 (3)ょり $\overline{d \sigma} / d \bar{\varepsilon}$ を求め $\overline{\varepsilon=0}$ と扑くとの值を得る。 


\section{図-10}

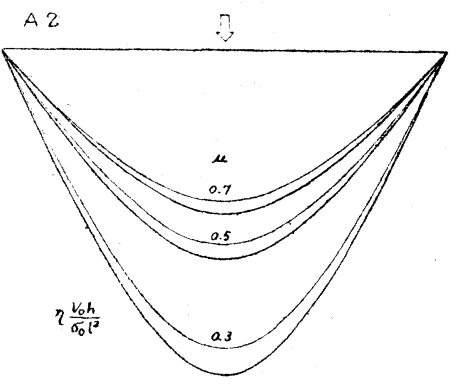

B 2

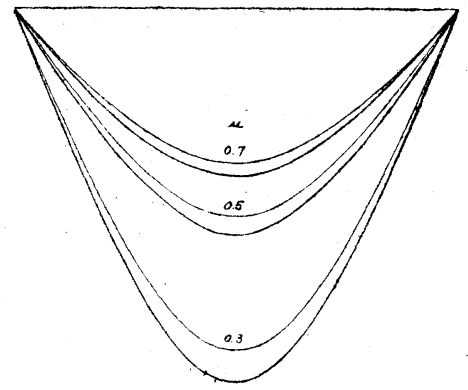

図-11
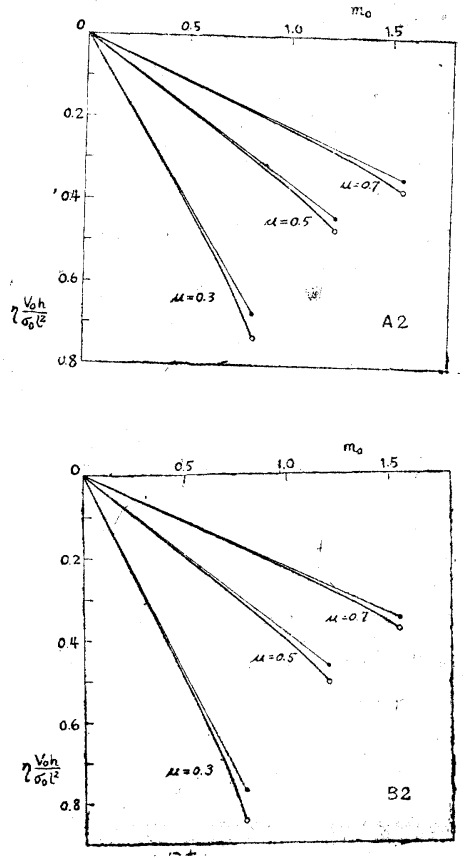

เつて

$$
\begin{aligned}
\psi_{1} & =\frac{2}{3} \xi-\frac{1}{3} \xi^{3}+\frac{1}{12} \xi^{4} \\
\psi_{3} & =\frac{16}{35} \xi-\frac{2}{5} \xi^{5}+\frac{2}{5} \xi^{6}-\frac{1}{7} \xi^{7}+\frac{1}{56} \xi^{8} \\
\psi_{5} & =\frac{256}{693} \xi-\frac{16}{21} \xi^{7}+\frac{10}{7} \xi^{8}-\frac{10}{9} \xi^{9}+\frac{4}{9} \xi^{10}-\frac{1}{11} \xi^{11}+\frac{1}{132} \xi^{12} \\
\psi_{7} & =\frac{2048}{6435} \xi-\frac{16}{9} \xi^{9}+\frac{224}{45} \xi^{10}-\frac{336}{55} \xi^{11}+\frac{140}{33} \xi^{12}-\frac{70}{39} \xi^{13}+\frac{6}{13} \xi^{14}-\frac{1}{15} \xi^{15}+\frac{1}{240} \xi^{16}
\end{aligned}
$$

梁の中点で $\xi=1$ と执いて

$$
\psi_{1}=\frac{5}{12} \quad \psi_{3}=\frac{93}{280} \quad \psi_{5}=\frac{793}{2772} \quad \psi_{7}=\frac{26333}{102960}
$$

$p$ が小さい間は式 (22) の第1 項げけとると

$$
\eta=\frac{\gamma \sigma_{0} l^{2}}{2 V_{0} h} k m_{0} \psi_{1}=\frac{\gamma \sigma_{0} l^{2}}{2 V_{0} h} \frac{\beta}{\sqrt{1-\alpha^{2}}} \frac{p l^{2}}{8 W \sigma_{0}} \frac{1}{3} \xi\left(2-\xi^{2}+\frac{1}{4} \xi^{3}\right)
$$

B2 の場合に

$$
\eta=\frac{5}{384} \frac{p l^{4}}{E J} \cdot \frac{4}{5} \xi\left(2-\xi^{2}+\frac{1}{4} \xi^{3}\right)
$$

となり弾性理論の結果と一致する。

本研究に於ける諸数值計算は宇田川和子君に負 万所極めて大である。附記して厚く謝意を表する。 